\title{
Entrevista \\ con Martín López Lam
}

Martín López Lam es un joven autor peruano, aunque lleva más de diez años residiendo en Valencia, desde donde desarrolla una intensa labor como ilustrador, dibujante de cómics y editor, a través del sello Ediciones Valientes. Cuando en CuCo, Cuadernos de cómic planteamos la posibilidad de realizar entrevistas con autores de cómic el nombre de López Lam fue de los primeros que nos vinieron a la mente, porque entendíamos que su figura y su obra, profundamente personal, son ejemplo de toda una nueva generación de creadores que están expandiendo los límites del medio. La entrevista, que se mantuvo a tres bandas a través de Skype entre el propio autor y los directores de esta publicación, revela a un autor que ante todo ha reflexionado sobre su trabajo y que tiene sus propias ideas sobre el arte y el mercado. 
¿Cómo comienzas a interesarte por el cómic? ¿Cuáles son tus primeras lecturas e influencias?

Creo que fue por el manga, cosas como los animes de Saint Seiya u Oliver y Benji, cuando cursaba la secundaria en Perú. Empecé a hacer con un amigo una especie de parodia de Oliver y Benji, nos inventábamos los equipos, las jugadas... En esa época yo no había visto aún el manga, sólo los dibujos animados. Los hacíamos en cuadernos que luego íbamos pasando a los compañeros de clase, y había algunos a los que les hacía gracia. Así empecé.

\section{O sea que a través del anime empiezas a hacer los} mangas que a ti te gustaría que surgieran de ese anime...

Sí, bueno, el cómic sí sabía lo que era. En toda América hay un cómic muy conocido, Condorito, del chileno Pepo, son tiras cómicas, que puedes encontrar hasta en las peluquerías. Pero de conocer eso a hacer un cómic hay un trecho, es otra cosa. El impulso me lo dio el anime, creo yo.

\section{¿Y luego vas descubriendo más cómics?}

Sí, claro. Lo que pasaba en Perú es que lo que llegaban eran cómics de saldo. Cimoc, Zona 84, El Vibora... todos retapados. También las ediciones de Zinco de DC Comics. Y así conocí otro tipo de historias. Recuerdo que El hombre que ríe de F. de Felipe me marcó mucho, por ejemplo. Otro modo para conocer otro tipo de

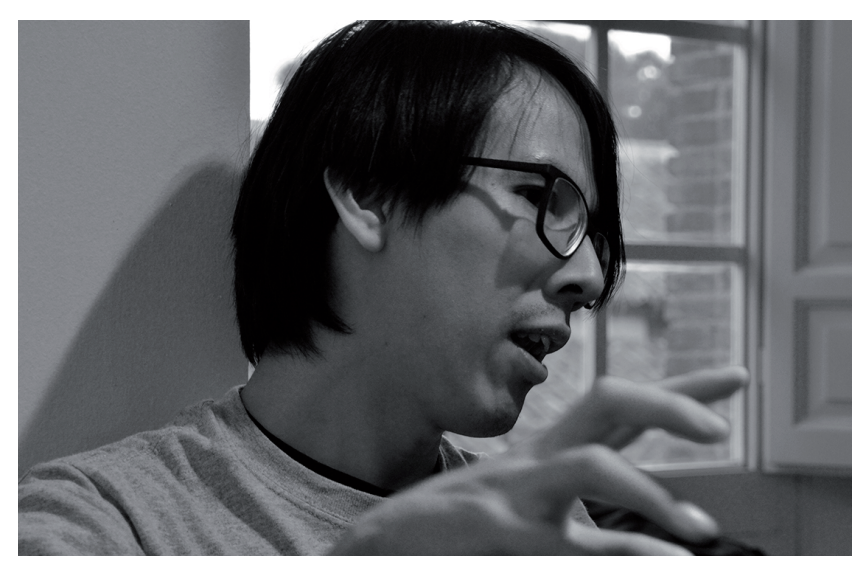

Martín López Lam. Fotografía de Alejandro López Menacho historieta eran ediciones pirata y las fotocopias, todas ellas con muy mala calidad. Por esta vía llegué a Enrique Breccia y otros autores argentinos de la época.

\section{¿No había en esa época cómic autóctono en Perú?}

Sí, sí. El cómic más mainstream, por decirlo de alguna manera, en Perú es El Supercholo. El cholo es el indígena andino. Y el Supercholo era una especie de reivindicación del indio mezclada con superhéroes. Fue creado en 1957 por Francisco Miro Quesada y Vitold Hogniman y ha tenido varias etapas. Tuvo una que coincidió con la época del terrorismo, en la que hacía mención a los guerrilleros y demás, pero luego tiene etapas completamente marcianas, en las que lo mandan al espacio, a otra galaxia, a jugar un partido de fútbol... No tenía ni pies ni cabeza [risas]. El Supercholo salía todos los domingos en El Comercio, el diario de mayor tirada en Perú. También había muchas tiras vinculadas con la Iglesia. La revista Avanzada era una de ellas, aunque es bastante más antigua y la conozco por un dibujante que me gustaba de niño, Javier Flores del Águila, que era una mezcla de Alex Raymond y Alberto Breccia. Y hay otro autor, quizás el más conocido dentro y fuera de Perú, Juan Acevedo, que sigue dibujando hoy. Es un dibujante de izquierdas y sus personajes son siempre progresistas y provenientes de estratos populares. El Cuy es uno de sus personajes más conocidos. Un cuy es un roedor andino y durante mucho tiempo fue un animal muy vinculado a la gente pobre y a los Andes, un rasgo del racismo que existe en Perú. Acevedo lo tomó y lo reivindicó: si Disney tenía a Mickey, que era un ratón, en Perú tenía que haber un cuy. El cuy iba a las huelgas con los profesores y los sindicalistas y a diferencia de los animales de Walt Disney, que iban vestidos, al cuy y a sus amigos les dibujaban el sexo todo el rato. Por internet el propio autor está subiendo muchas tiras antiguas.

Y ese es el tipo de cosas que uno lee de chiquillo: tiras cómicas, humor... Aunque lo de Acevedo era algo totalmente adulto, aunque yo lo leyera 


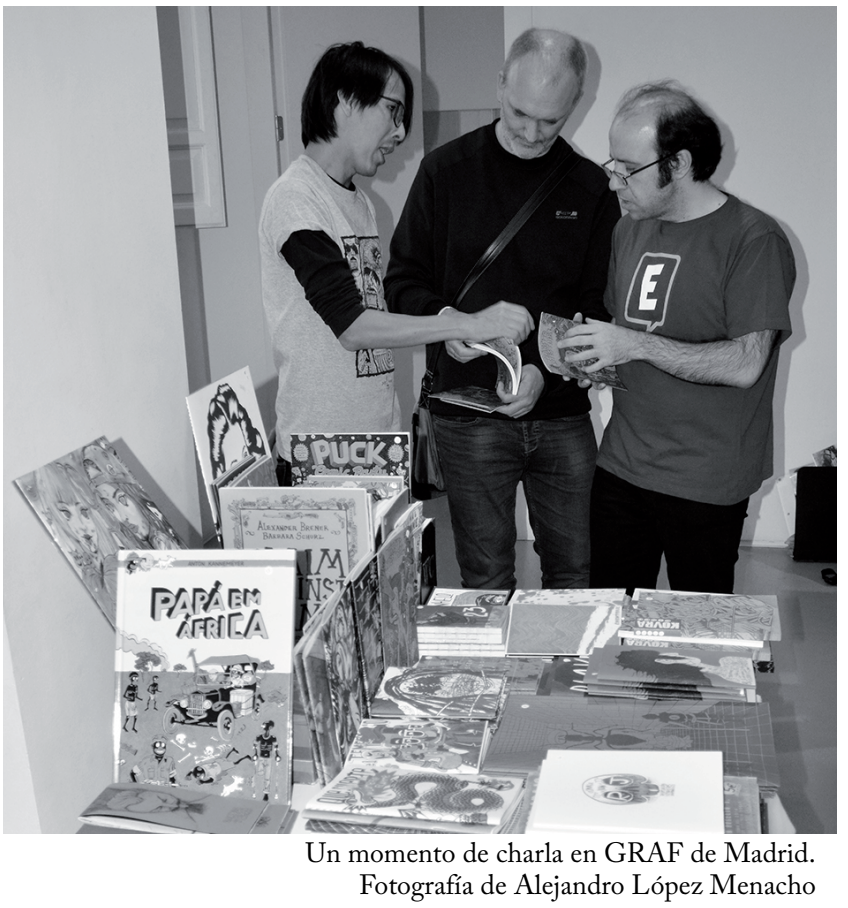

de niño, sus historietas siempre han estado en un campo de lo social y por eso han llegado a muchos sitios. Acevedo de hecho ha sido educador, creo, y sus viñetas son muy didácticas. Han sido un medio con el que era muy sencillo enseñar a la gente normas básicas de higiene, por ejemplo, o hablar de problemáticas en determinados barrios.

\section{Tú estudiaste Bellas Artes en Perú.}

Sí, así es. Me especialicé en grabado y después empecé a trastear con las máquinas, dispositivos interactivos... Lo que ahora se llama net.art. Como allí no estaba muy desarrollado este campo me vine a Valencia a continuar mis estudios, que tiene una buena facultad. También vine porque entonces el euro valía menos que el dólar, y estudiar aquí era mucho más barato que estudiar en Perú.

\section{¿En qué año viniste?}

En el 2003.

¿Cómo se retroalimenta todo el mundo de las Bellas Artes con la afición por el cómic, hay influencias mutuas?

Sí, existe un vínculo claro, que es la gráfica. Yo digo que antes que autor de cómic soy grafista y dibujante. $Y$ en realidad lo que muchas veces he hecho es una narración a través de la obra gráfica, que la obra esté contándote algo. En una ocasión una galerista con la que trabajaba se refirió a mis dibujos como cómics, aunque eran dibujos sueltos de 2 × 2 . Pero sí partían de cierta narración. Tú veías el dibu-

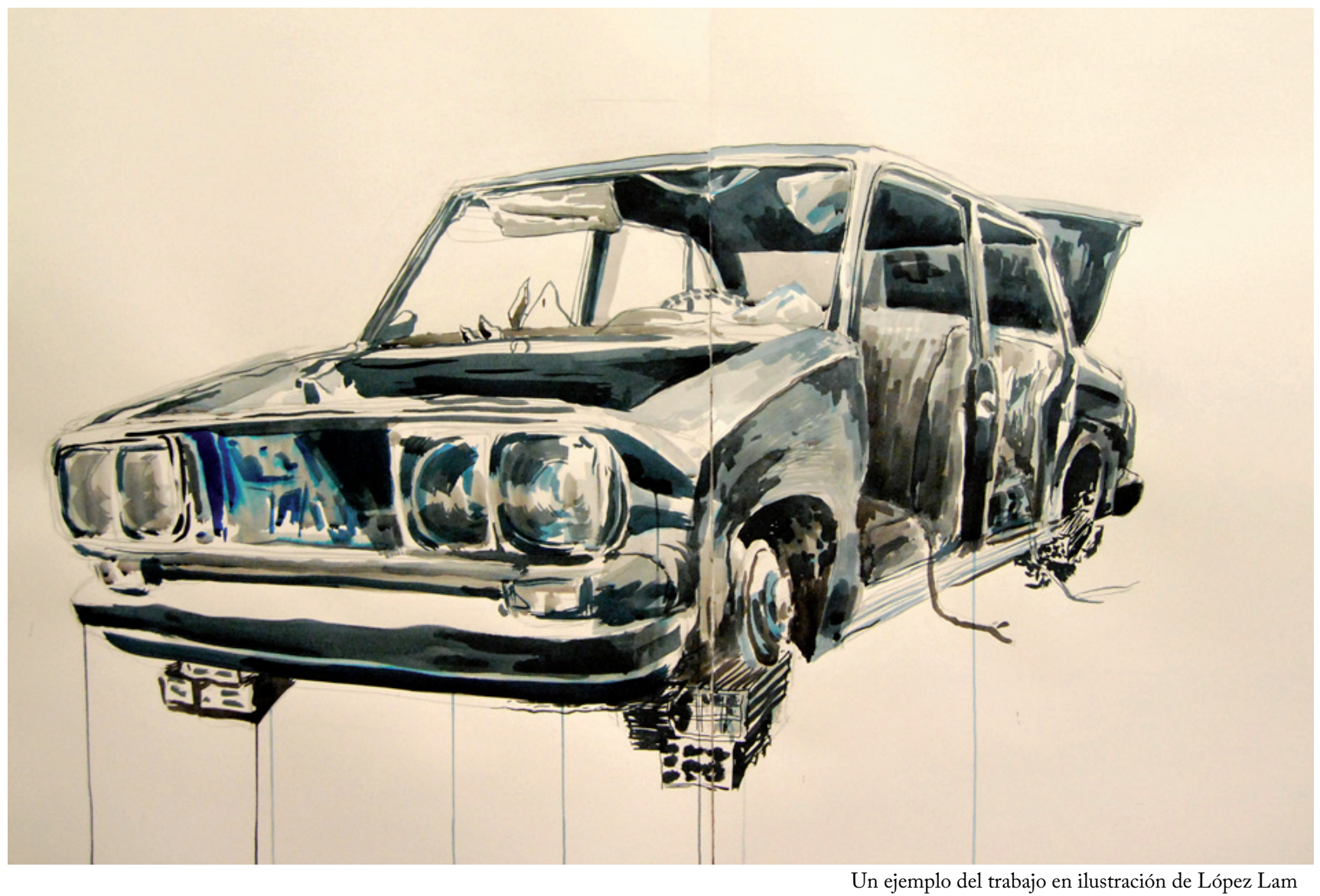


jo y podías armar una historia. Es algo en lo que he ido pensando conforme seguía trabajando: cómo todo me ha empujado a la narración. Además tuve la suerte de que nunca un profesor me dijo que el cómic no es arte, que es algo que cuentan muchos dibujantes de cómic y a mí nunca me pasó. Ambas cosas las he llevado siempre en paralelo.

\section{$¿$ ¿Durante tus estudios universitarios ibas reali- zando cómics, o eso empieza después?}

Allá en Perú hice cómics durante mucho tiempo. Me juntaba con amigos que eran también aficionados al manga, y formamos un pequeño club de cómic donde dibujábamos. Con ellos empecé a hacer fanzines, porque era la única forma de publicar nuestras propias cosas, dado que aún no había internet. Teníamos que mover nosotros los fanzines de sitio en sitio. Hubo una etapa en la que no hice nada de cómic, porque estuve muy centrado en otras cosas. Igual fueron cuatro o cinco años. Pero cuando hacía cómic lo hacía de una forma mucho más pausada y relajada que ahora, que estoy dibujando y escribiendo todo el tiempo.

¿Concibes el cómic como una parte central de tu trabajo, o es más bien algo englobado dentro de lo gráfico?

Creo que es más bien un todo, en realidad, no lo veo como algo aparte.

¿Qué piensas que es lo específico del cómic? Has hablado de narración... ¿la consideras imprescindible para hablar de cómic?

Es una pregunta un poco trampa [risas]. En mi caso hay veces en las que la historia surge antes que el dibujo, mientras que en otras piezas de dibujo artístico surge antes la imagen que la historia. $\mathrm{El}$ proceso es diferente. Ahora por ejemplo estoy haciendo un cómic sobre el trabajo, y en este caso he decidido partir de la historia. Podría haberla enfocado desde las imágenes, pero sería diferente. Sí que a veces hay imágenes que he creado para piezas artísticas que después han acabado en un cómic, y viceversa. Hay ideas que se van trasladando de un sitio a otro, traduciendo en diferentes lenguajes. En los dibujos a veces me doy cuenta de que la imagen que estoy dibujando es muy anecdótica, con una carga narrativa muy fuerte que el espectador va a sentir. $\mathrm{Y}$ en el cómic me pasa lo contrario: quiero a veces hacer cosas que no sean narrativas. De todas formas no tengo muy claro qué es lo específico. Hace poco alguien me preguntó qué diferencia hay entre un libro ilustrado que cuenta una historia secuencial página a página con un cómic. No pude ayudarle, incluso, al contrario, me dejó todo contrariado al darme cuenta que no había comprendido nada en todos estos años.

Al final todo es una vía para crear arte, todo es compatible. ¿Qué ves tú que puede ofrecer el cómic que no ofrezcan otros medios?

Cierta intimidad. Es un poco cursi decirlo así, pero hablas directamente al lector, como cuando lees que inconscientemente reproduces un sonido dentro de tu cabeza, y ese falso sonido te va metiendo en un trance. A pesar de que lo que cuentes puede ser muy anecdótico, un simple gag, en la historieta la relación que se da entre los conceptos tiempo / espacio / movimiento dentro de la misma página es siempre muy poderoso, y es algo que no te ofrecen otras disciplinas. Es lo que hace que el cómic me guste más que otras cosas. Por ejemplo cuando hago una lámina de serigrafía lo primero que quiero es "engatusar" al espectador, atrapar su mirada para luego llevarlo a otro lado, mientras que cuando hago un cómic quiero "engatusarlo", pero sobre

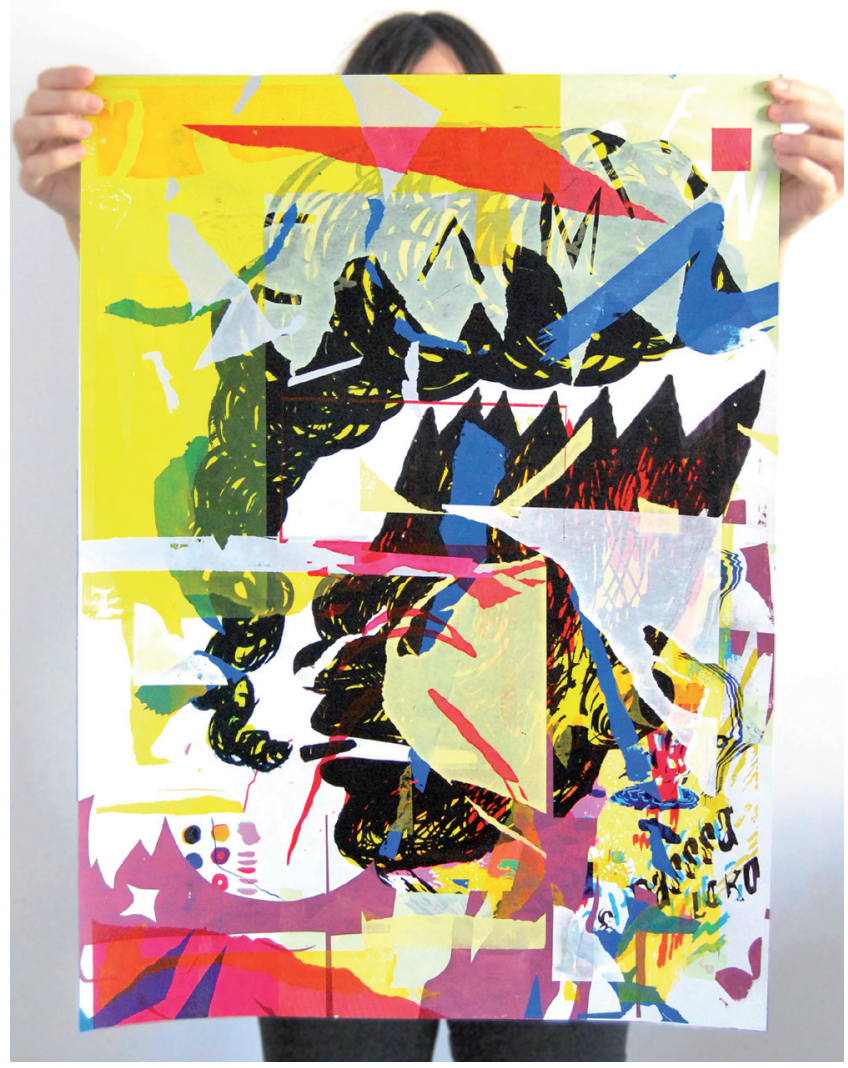

Una de las serigrafías del autor 
todo que comprenda que lo que está viendo es un mecanismo de montaje, que no es una cosa natural. Es menos sensorial que otras artes, y te permite otro tipo de percepción, quizá más cerebral.

\section{Tiene más artificios.}

Claro, es puro artificio, no hay nada que te sujete a la realidad. Cuando haces un cómic es imposible hacer una referencia directa a la realidad, todo es gráfico. Es un montaje constante.

Javier Olivares comentaba precisamente eso mismo: que el cómic no puede pretender el engaño de simular la realidad, sino que la filtra, la interpreta.

Claro, es un proceso mental, intelectual, bastante más que el cine, por ejemplo. El cine me parece el arte por excelencia, conste, pero en él sí tienes el referente directo de la imagen, más aún en el cine documental o en el cinema verité. Puedes capturar el momento con una cámara, pero eso es imposible en el cómic. Y esto te obliga a repensar todo de otra forma.

Es hacia donde va el cómic contemporáneo: se están dejando de lado los estilos más pretendidamente realistas o naturalistas y se manejan otros códigos.

A mí lo que más me interesa ahora mismo es el concepto del montaje: cómo se construye la historia a partir de la secuenciación de las imágenes, que ni siquiera tienen que ser de la misma naturaleza o del mismo autor.

No tienen que ser consecutivas, no tiene por qué haber una continuidad: las secuencias non sequitur de Scott McCloud...

Sí, podría ser eso, pero hay que hacerlo con una intención... En todo arte tú creas un andamiaje... Es lo que decían de Alan Moore, que creaba catedrales. Eso me gusta, pero también me gusta la idea de decirle a la gente que todo lo que está leyendo es mentira: enseñarle las costuras de la obra intencionadamente. Desengañarlo, marcar la distancia entre el lector, la obra y el autor.

Sí, no "engañarlo". Cambiando de tema, ¿crees que el cómic tiene un lugar en el mercado del arte contemporáneo?

Creo que hay cosas interesantes. Martín Vitaliti, un argentino que trabaja a partir de recortar imágenes de superhéroes y hacer collages... Francesc Ruiz también me parece interesante, también parte del cómic para hacer sus piezas. Pero el cómic es un arte muy ligado a la edición, al formato del libro, y hacer un cómic para exposición puede ser muy aburrido. En general las exposiciones de cómic son muy aburridas y cuando se trata de poner originales o bocetos creo que solo interesa a otros dibujantes. La idea tendría que ser hacer un cómic pensado para la exposición. En los sesenta y los setenta hubo una teoría de un hippie americano, Gene Youngblood, que

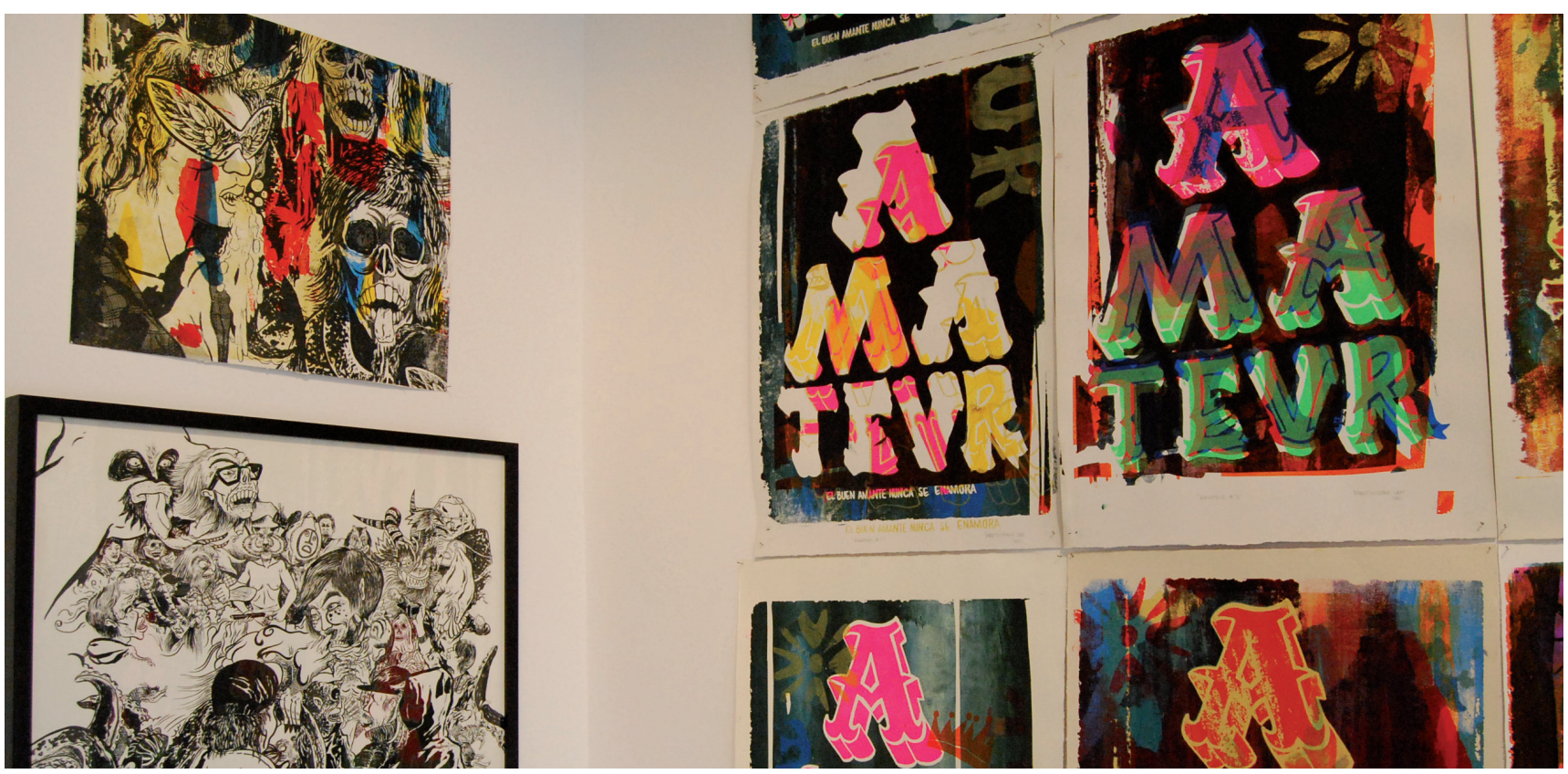

Una exposición con el material de López Lam 
hablaba de cine expandido. Él comentaba que el cine pasaría de los grandes estudios a pequeños formatos, que es más o menos lo que ha pasado, pero además decía que se vincularía con el arte y rompería el espacio expositivo de la pantalla, y pasaría a ser proyectado en paredes, o a través de múltiples pantallas. Son cosas que han terminado pasando. Un ejemplo cercano de esto es la obra de José Val del Omar. Recuerdo la retrospectiva que se hizo en el Reina Sofía hace unos años, fue increíble. Había múltiples pantallas o proyecciones que se desbordaban por los laterales de la sala dejándote totalmente inmerso en una experiencia narrativa, en una película. Creo que si el cómic tiene que entrar en ese mundo de las galerías y del arte expositivo tiene que generar una especie de experiencia narrativa. No sé si el ejemplo más claro puede ser Fabricar historias de Chris Ware. A la vez que estás leyendo estás interactuando con la pieza. Me imagino que en lugar de ser una caja que manejas en casa podría montarse en un espacio tridimensional por el que la gente puede pasear, a través de la historia. Aunque igual esto ya no sería cómic.

\section{Al hilo de esto, nos gustaría preguntarte por el circuito del cómic más alternativo, no sabemos si podría llamarse underground, por el que tú te has movido como editor $y$ autor. ¿Crees que po- demos hablar de un circuito en España?}

Sí, definitivamente hay un circuito. Solo hay que ver la cantidad de festivales que se organizan y cómo se relacionan entre ellos. Se está creando una especie de red de festivales: en Facebook hemos hecho la página del Nuevo Frente Popular Para La Liberación Gráfica [risas]. Es una broma, pero estamos intercambiando datos y fechas para que los diferentes festivales no coincidan en los mismos días, que es una pena cuando sucede. Tenemos el GRAF, el MEA, el BALA, el Gutter, Tenderete, GrapaGrapa... Todos estos festivales son síntoma de que hay gente haciendo cosas y no están esperando ser el anexo de una gran feria del cómic o del libro, sino que están generando su propio evento. Lo ideal sería que en cada ciudad surgiera uno, con su propia personalidad y su propio público. Todo esto es lo interesante, pero luego, como en todo, hay cosas que para mí no valen la pena (gustos personales) aunque sí la valen en el sentido de que lo hace alguien que se lo curra por sí mismo. La autoedición siempre tiene un valor intrínseco, no se le puede quitar mérito. Pero hay cosas que en el fondo son como un salón de cómic más o como lo que podríamos encontrar ahí. También hay un valor crítico en la autoedición, en la pequeña edición, o en la edición independiente, más allá de que el autor perciba un mayor porcentaje de la ganancia o que se encuentre libre de censura externa, y es que no le veo ningún sentido (y eso es una cuestión estrictamente personal) pretender ser independiente si vas a publicar lo mismo que publicaría una revista o una editorial masiva. Quiero decir que tanto estética, como temática y económicamente, este tipo de publicaciones debería suponer otra cosa. En el fondo, más allá de que a un dibujante le paguen/gane más o menos, y en si, cualquier trabajador, hay alguien más grande que se está beneficiando de tu trabajo y de las cosas que haces, llámalo macroeconomía, stablishment o illuminatis, no puedo dibujar como los autores que dibujan para aquello con lo que no estoy de acuerdo.

\section{¿Consideras la autoedición como una opción comercial más, o implica un posicionamiento ideológico de alguna clase? ¿Hay una ética de la autoedición?}

El hecho de autoeditarse ya está marcando un posicionamiento político e ideológico. Está dentro del mercado dependiendo de a qué llames mercado: si quieres vender millones de copias, tendrás que entrar a jugar con mecanismos de márketing para saber qué le gusta a la gente y vendérselo, aunque si ya te conocen o eres demasiado popular, igual ni falta te hace, vas a seguro... Yo tengo mi público y sé hasta dónde quiero crecer con lo que hago. No es tanto ponerle techo como saber hacia dónde quiero ir. Hacer tiradas muy grandes o llegar a mucha gente no creo que sea lo mío o lo de Ediciones Valientes. Pero sí es necesario que se mantenga por sí misma, que no sea un capricho, que cada vez que se quiera editar algo no haya que desembolsar dinero, sino que los beneficios permitan su funcionamiento, que haya una economía sostenible. Así como en la alimentación existe el mercado ecológico, donde le compras directamente al agricultor, en la cultura es lo mismo. No estás consumiendo grandes exposiciones de museos, sino exposiciones pequeñas en asociaciones de barrio, o comprando pequeñas publicaciones directamente al autor o a un colectivo de autores. El contenido que tengan las publicaciones ya es cosa tuya. 
Yo recurro a la autoedición porque cuando empecé a dibujar con los colegas aprender a editar era una necesidad. Y cuando llegué a España ya había adquirido el vicio de publicar fanzines. Aquí la industria del cómic te empuja a determinadas líneas, $\mathrm{y}$ si no las sigues te quedas fuera, aunque parezca que existe mucha libertad creativa visitando cualquier librería te darás cuenta de qué estilos gráficos y qué temáticas se publican. Muchas veces esas tendencias vienen de afuera, también. Pero bueno, así son las leyes de la oferta y demanda. Antes de meterme a dibujar cosas que no me interesaban (o que no me salían) preferí montar mi propia publicación. Como dice el dicho, si no puedes meterte en la casa por la puerta, prueba por la ventana o por la chimenea, y si no logras colarte, tal vez sea mejor construirte tu propia casa en otro sitio. Creo que la gente empieza a autoeditarse para tener un espacio propio. $Y$ esto es interesante porque lo que ha surgido con la autoedición - y cuando digo autoedición me refiero por extensión, aunque no lo sean, a la microedición - en España son básicamente espacios para que la gente se conozca e intercambie ideas y experiencias para producir otro tipo de contenidos y estéticas. Antes esos espacios se veían confinados a los salones del cómic o del libro, o cosas mucho más elitistas, como inauguraciones. Generar espacios como el Tenderete, el Gutter Fest, el BALA, el MEA, el FLIA o el GRAF es importante porque el propio público que asiste se da cuenta de que ellos también pueden hacer este tipo de cosas, y se quitan la idea de que uno tiene que llevar el proyecto a una editorial para que se

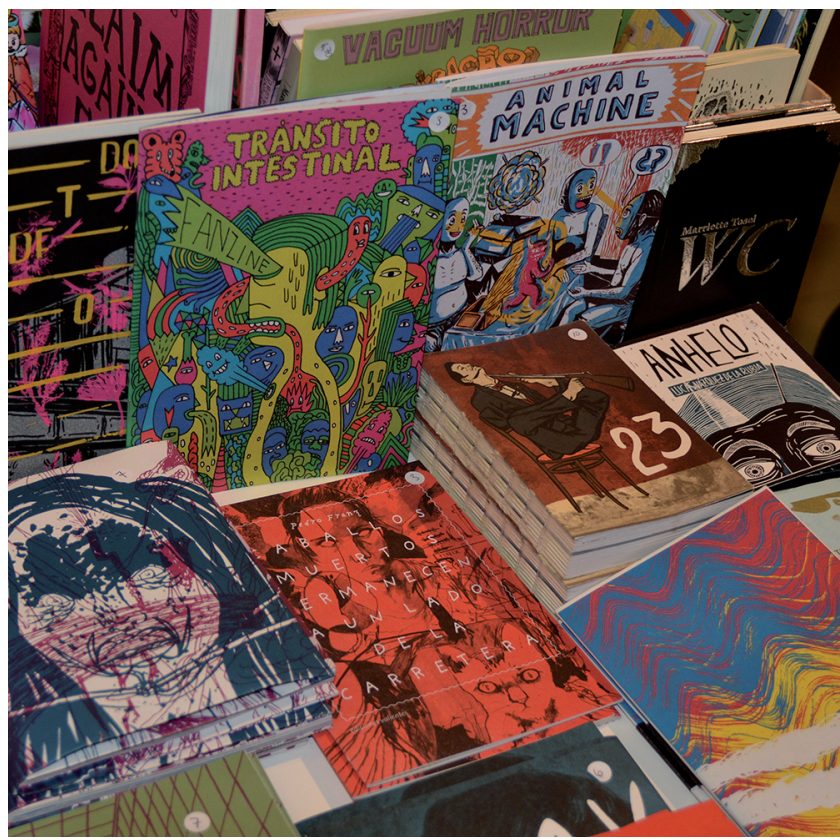

El material de Ediciones Valientes expuesto en el GRAF de Madrid. Fotografía de Alejandro López Menacho lo publiquen necesariamente... No, puedes ir a la fotocopiadora, hacerte unos cuantos ejemplares y estar aquí también. En el Tenderete ahora mismo la mitad de participantes fueron antes espectadores. Es muy enriquecedor.

\section{¿Cómo nace Ediciones Valientes?}

En 2007 yo había terminado la carrera junto con una amiga, Irene Pérez, y con Esteban Hernández, que ya hacía el Usted, con el que coincidía en algunas clases. E intentamos crear una especie de estudio de ilustración para ganarnos la vida. Gráfica Valiente era el nombre del estudio. Yo quería hacer un fanzine con unos dibujos que había hecho para mi primera exposición individual en una galería seria. Fui a hablar con la galerista y le pedí algo de dinero para editar el fanzine con los dibujos de la exposición, pero ella me dijo que mejor pagaba todo y la publicación serviría como publicidad de la expo. Creo que la engañamos un poco [risas]. Aquello acabó siendo El temerario n. ${ }^{\circ}$ 1, y supuso el arranque de Ediciones Valientes. Después a Esteban empezó a irle mejor en el cómic, a Irene le fue mejor en el diseño y se fue a trabajar a $\mathrm{Ma}$ drid, y a mí me iba bien con las exposiciones, así que el asunto se quedó un poco disuelto. Hasta que en 2010 me propuse retomar la idea de Ediciones Valientes y empezar a editar fanzines de diferente índole. Y así saqué el número 1 de Kovra.

\section{E1 Kovra lleva ya cinco números.}

Sí, y en breve saldrá el sexto.

Una de las cosas que siempre nos ha llamado la atención de él es su vocación internacional: hay nombres implicados de un montón de países diferentes. ¿Esto surgió sobre la marcha o parte de una intención por tu parte?

Sí, desde el principio fue esa la intención, lo que pasa es que no fue hasta el tercer número que se hizo internacional, con páginas de Berliac, Power Paola, Ricardo Martins... Pero tenía que ir poco a poco. El primer Kovra tenía solo veinticuatro páginas, bastante sencillo, y en cierta forma ya era internacional porque estaba yo, que soy peruano [risas], y Rodrigo la Hoz, también de Perú, Pablo Soto, argentino aunque viviendo en Barcelona... Siempre tuvo esta intención de ser internacional, porque como dibujante yo siempre estoy buscando 


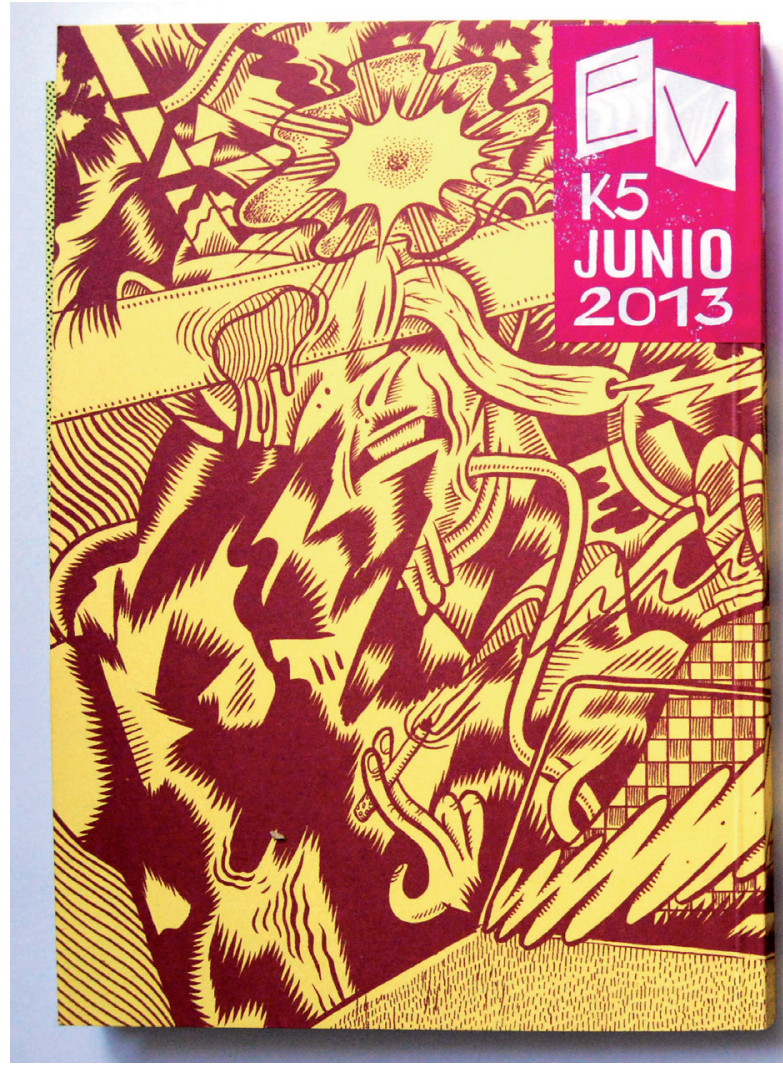

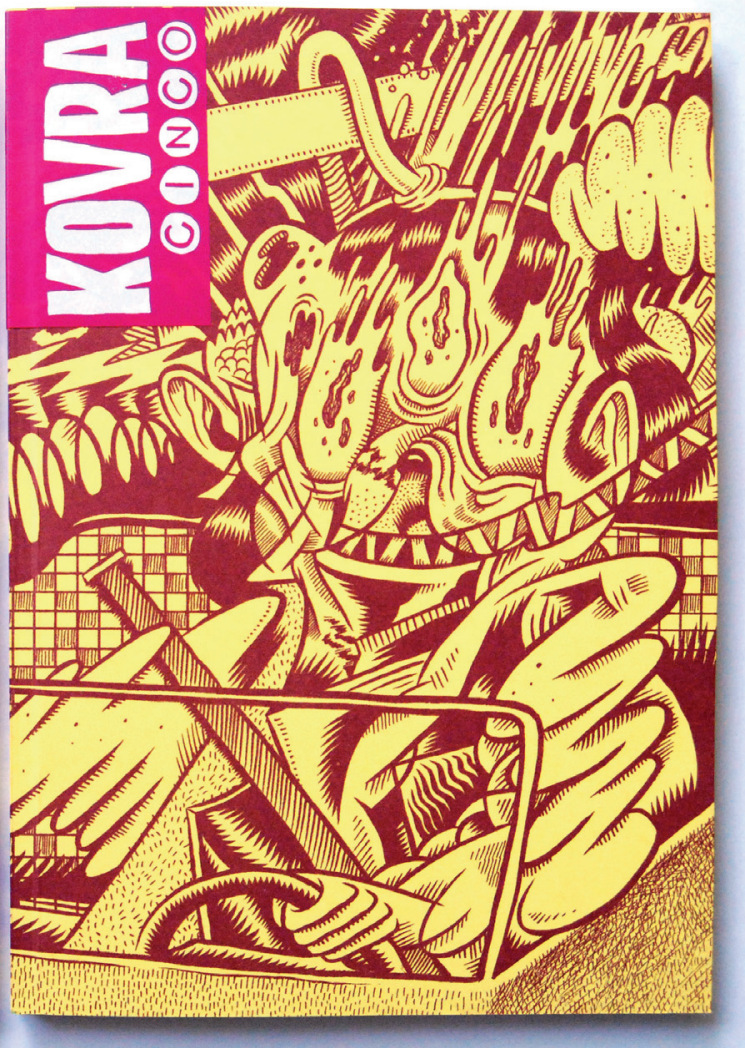

El número cinco de Kovra mantener contactos con otros autores. Todos los autores que iba conociendo que me parecían interesantes quería darlos a conocer a otra gente. Tanto el Kovra como El Temerario son parte de esta búsqueda de autores. Me interesaba también acercarme a países que no fueran los típicos productores de gráfica: EE. UU., Francia, Japón, Bélgica...

Sí, países con los que en general no asociemos el cómic.

Claro, o que no conocemos nada, como pasa con los autores de Croacia o Serbia. Allí hay autores bastante experimentales, que también trabajan en el campo de la autoedición. Y conectar con ellos me resultaba muy estimulante. Son gente que está produciendo obra en condiciones económicas muy jodidas, que se mueven... Te das cuenta de que no todo tiene que ser el festival de Angoulême.

Además de estas obras con colaboraciones de muchos autores estás publicando en los últimos años muchas obras monográficas de autores latinoamericanos: Berliac, Pedro Franz, Inés Estrada... ¿Cómo surge todo esto?

Tiene que ver con el idioma. Si bien me interesan muchos autores croatas, serbios o portugueses, el trabajo para editarlos sería más laborioso. Y mi inglés no es tan bueno, no ya para traducirlos, sino para venderles la idea de publicarlos. Además también coincide que conozco a muchos autores de Perú, de México o de Colombia que hacen cosas muy particulares, que no respondían a una estética o a una forma de narrar occidental, sino que estaban asociadas a los movimientos propios de cada región. Y creo que España tiene mucha más relación con América que con Europa: la lengua es una cosa tan potente que funciona no solo a nivel del mercado, sino también artístico. Y además yo soy americano y me interesa lo que se hace en el continente.

A pesar de que, como dices, el idioma debería unirnos, aquí conocemos muy poco del cómic latinoamericano contemporáneo. ¿Se están haciendo cosas interesantes ahora?

Sí. Hace poco estuve en Colombia, en el festival de Entre Viñetas, que es un festival único en su formato. Es un festival itinerante, llevan a los autores a Colombia y los mueven por varias ciudades, dando charlas, haciendo talleres, expos... Por allí han pasado Mireia Pérez o Santiago García. No está centrado en la venta de libros, sino en la teoría y en el aprendizaje. Y van autores europeos 


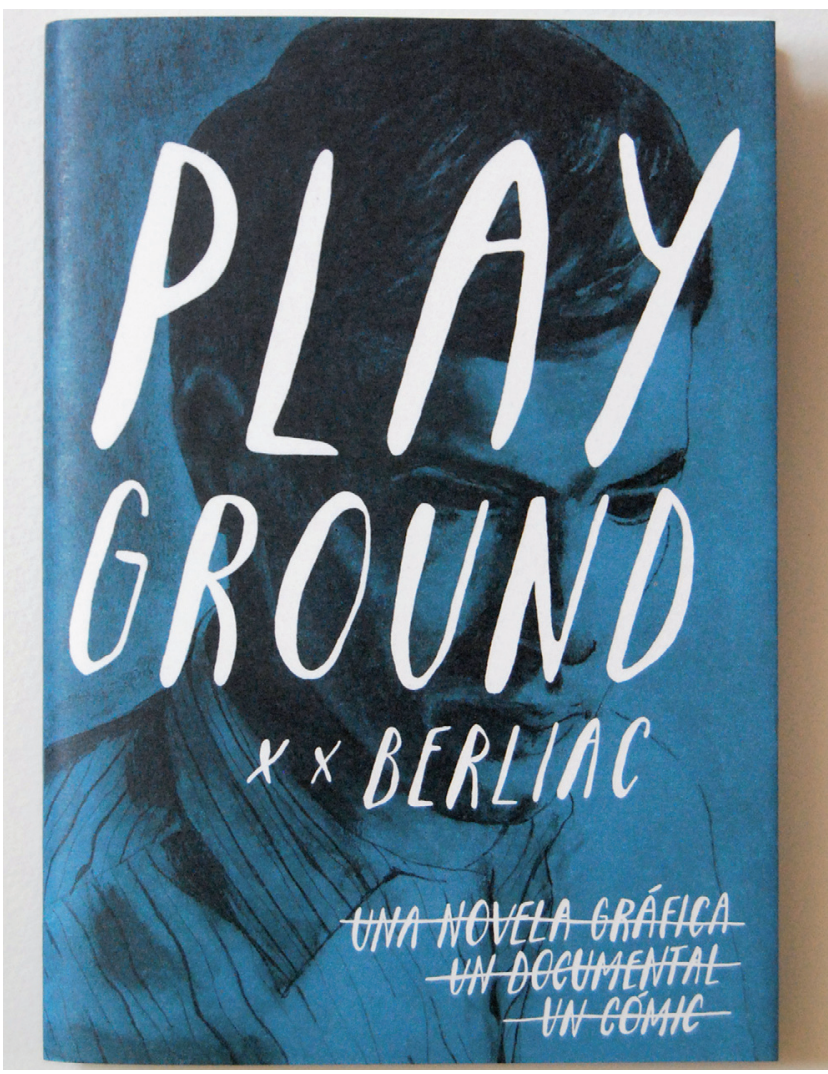

Portada de Playground, la obra de Berlia publicada por Ediciones Valientes

de vanguardia, como Olivier Schrauwen o Ben Newman, editor de Nobrow... Están pendientes de lo último e intentan llevar un poco de todo eso para allá. Por otro lado Power Paola me parece la autora latinoamericana por excelencia ahora mismo. Es una cosa única que ha generado, como es normal, imitadores. Cuando lees sus cómics puedes ver referentes: Julie Doucet, Ulli Lust... Pero sientes que no es solo eso, que tienen una personalidad propia. Inés Estrada también me parece una autora única, más cercana al underground norteamericano, aunque también sientes cuando lees sus cómics que son completamente mexicanos. Me parece interesante cómo son capaces de situarte en un sitio específico. Abraham Díaz me parece un dibujante increíble, súper bizarro. Rodrigo de la Hoz, Jorge Ruibial, Jesús Cossio, Eduardo Yaguas o David Galliquio en Perú; Mou y Apollo Cacho en México también; Maliki, una chilena que recién he conocido hace unos meses me parece muy divertida y sincera, hace esos cómics de autoedición que de verdad te encandilan y divierten. En Colombia M. A. Noregna, que es el man de los fanzines por allá, Jim Pluk o Joni B.

Ahora parece que todos fueran chicos pero también hay mujeres. Es más el cómic latinoamericano he- cho por mujeres también es una rama fuerte. Hace unos meses se hizo una nueva edición del festival Lima en Cuadritos y estuvo dedicado exclusivamente al cómic femenino: Sole Otero, Susana Villegas o Mariana Gil, por ejemplo, estuvieron ahí dando charlas y talleres.

Berliac es único. En Brasil también hay muchos autores: Pedro Franz, Diego Gerlach, Luiz Berger, Gabriel Goes... A pesar de que hablen en portugués se les entiende bien [risas].

Creemos que esto es parte de algo más grande, que es la manera en que se ha roto con los códigos de los géneros tradicionales y el cómic más comercial, o más masivo. La gente ha empezado a hablar de lo suyo, de la vida, de su entorno... Y creemos que esto es lo que ha permitido que los autores hablen de la idiosincrasia de cada país.

Sí, creo que es lo que decís. Lo íntimo y cotidiano además deja entrever otras realidades. En Entre Viñetas estuvimos hablando de esto en una mesa redonda, precisamente: del nuevo cómic latinoamericano, cuáles son sus rasgos. Estaban Catalina Bu de Chile, Inu Waters de Colombia, Marco Tóxico de Bolivia, Berliac [de Argentina], Bef de México y yo. Hubo una discusión bastante seria en torno a por qué se nos está englobando a todos juntos, a qué responde todo esto. La tradición en Latinoamérica es más del humor gráfico, de la tira. Pero decir que el cómic latinoamericano es Mafalda, El Eternauta o Condorito ya no es cierto. Ahora hay más influencia del underground americano, de la novela gráfica o del anime que del propio cómic que surgió allí. Y también se ha dado un debate sobre qué temas tienes que tratar cuando eres latinoamericano. Es un debate que existió en el cine y en la literatura también: los temas de la narrativa de periferia. Creo que los autores de cómic se están quitando eso de encima: no hay que hablar de pobreza, terrorismo, narcotráfico, dictadores o realismo mágico... Vamos a centrarnos en hablar de nuestras cosas, que además van a dejar entrever todo eso otro. Solo que ya no es el tema central, es una parte. No es Persépolis de Marjane Satrapi, que más allá de que fuera su vida tenía mucho que ver con el momento. Esto igual es hasta más ligero, pero aunque no hablemos directamente de grandes temas o problemas sí que hablamos de ellos. 


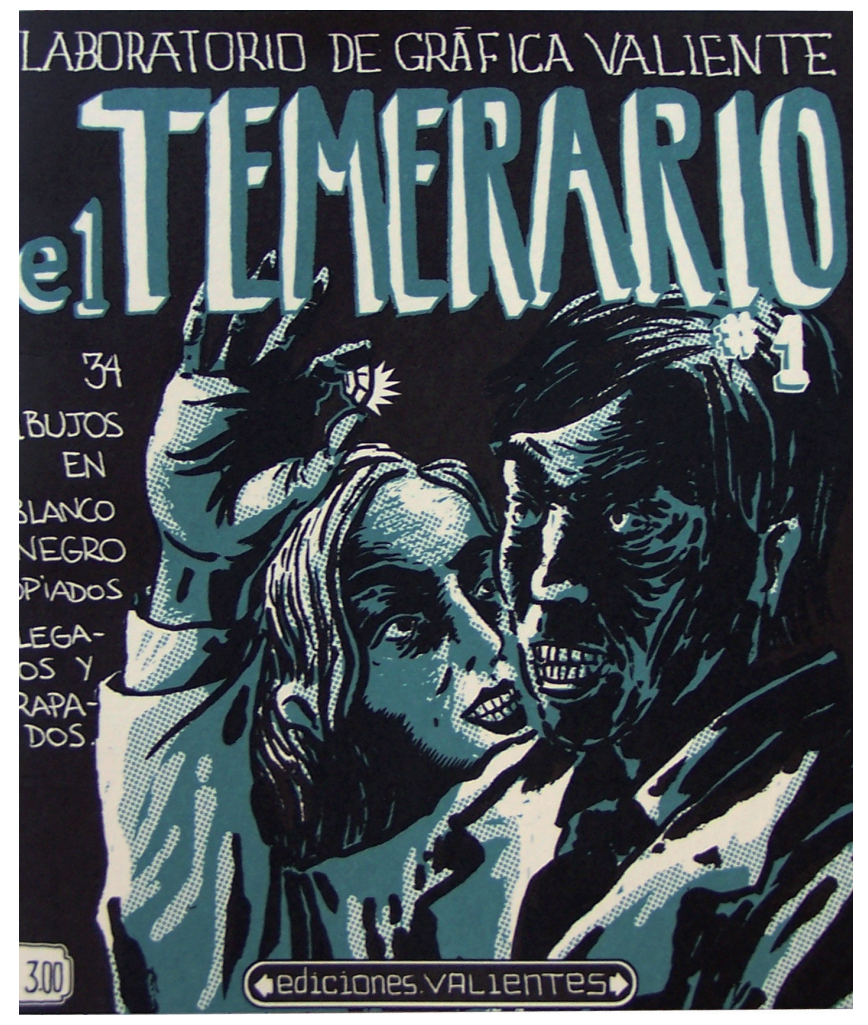

Cubierta de un número de El Temerario

Nos llama la atención que en Ediciones Valientes hay muchos subsellos, muchas colecciones. ¿Cuál es el objetivo de esto?

Marear a la gente [risas]. Que crea que es mucho más grande de lo que es [risas]. A veces me da por estas cosas. Está lo central: El temerario, que es lo más antiguo y que posiblemente cambie de formato y de propuesta en su próximo número. Después está el Kovra. Y la colección RA, que es para autores del Kovra. A veces llega algo que no encaja en los formatos de las colecciones que ya tengo, como pasó con Caballos muertos permanecen a un lado de la carretera de Pedro Franz, así que inicié una nueva. Tengo un par de historias que saldrán ahí en el futuro. Después tengo la colección NN, que es de fotocopia y risografía, que surgió porque no tenía suficiente dinero en ese dinero para editar en offset. En esta colección van a salir muchas cosas porque es económico.

Hay otro fanzine colaborativo reciente, Niños de Komodo, hecho bajo las reglas del taller OuBaPo. ¿Nos puedes explicar cómo funciona este método?

Eso fue el año pasado junto con Álvaro Nofuentes, un dibujante de Alicante que vive en Valencia, y que también forma parte de Ediciones Valientes, al que se le ocurrió la idea de ponernos a dibujar haciendo ejercicios como los del OuBaPo. Nos re- unimos durante todo el 2013 una vez al mes. También estaban Esteban Hernández, Elías Taño de Arròs Negre, Carlos Maiques, Peter Jojaio, Carlos Santonja, Ernest Graves y otros... Y nos dedicábamos a pasar la tarde dibujando. Lo primero que se nos ocurrió fue publicar los ejercicios en una especie de blog, pero nunca llegó a materializarse. Pero coincidiendo con un Tenderete se nos ocurrió sacar la publicación, en el que la premisa era que no hubiera ninguna firma. Puedes reconocer el estilo de cada autor pero las páginas no van firmadas. Eludir el nombre del autor a favor del nombre de la publicación, de la idea, era el objetivo. Un error que cometimos creo que fue no publicar las normas que seguimos para hacerlo... pero en realidad era una cosa que hicimos para divertirnos. Espero repetirlo en alguna ocasión.

Nos has comentado que el próximo Kovra está cerca. ¿Nos puedes comentar alguna otra novedad para los próximos meses?

Este Kovra puede que sea el último, porque creo que ha habido un cambio y quiero hacer otro tipo de publicación contando con los mismos autores. Después hay un cómic de un austriaco, Helmut Kaplan, un autor que tiene un colectivo, Tonto Comics, donde la mayoría de participantes no son exactamente dibujantes de cómic, sino artistas y músicos que también dibujan. Editan una revista que es una especie de remezcla de muchos dibujos. En cada número hay un tema - la música, los cuentos, el polo- y cada uno dibuja por separado y luego se mezclan los dibujos para construir una historia. El autor está supeditado a algo mucho más grande: la obra.

Nos traes a la cabeza lo que comentabas antes del cómic como constructo, hasta sus últimas consecuencias, además.

Claro. Cuando lees la revista hay una historia detrás, y cada autor tiene su personalidad propia y se puede identificar. Pero cuando lo ves en general es más una pieza completa que un conjunto de historias, como sí lo era el Kovra, que me gusta mucho y creo que tuvo algún valor... Pero ahora no me apetece hacer eso, sino una historia obra de muchos autores del estilo de Tonto Comics. También va a publicarse el cómic de una francesa, Lisa Lugrin, y espero que salga alguna cosa más: un cómic largo de Abraham Díaz, cuando lo termine de dibujar. 


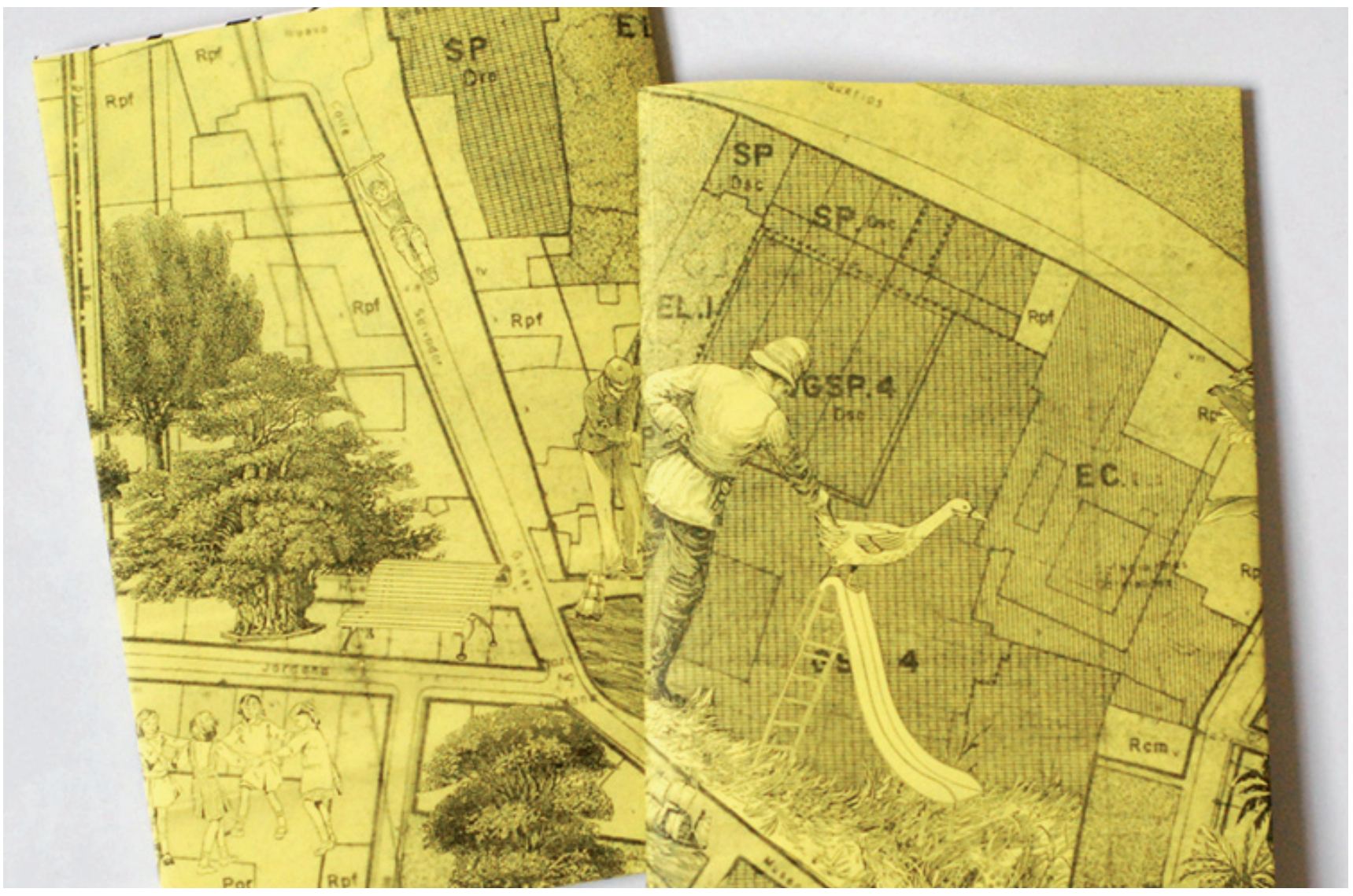

Portada de Niños de Komodo

Me gustaría tener dinero para editar muchas cosas [risas], también de gente de aquí como Victor Dvnkel, Carlos Santonja o Carlos Maiques (y tantos otros), así como proyectos deficitarios que son necesarios para romper ese aburrimiento que resulta de lo tan divertido que es el glamouroso mundo del comic indie nacional. Instaurar un nuevo orden mundial, la nueva crema.

\section{¿Qué tiradas manejáis en Ediciones Valientes?}

Depende. Cuando tiramos en offset sacamos quinientas, seiscientas copias. A los autores les pago en ejemplares, por lo general, así que cien o ciento veinte son para el autor. Otros treinta se van para regalos o prensa.

\section{Pero son fanzines, no hay ánimo de lucro, ¿no?}

No, claro, se cubren los costes y si hay ganancia se invierte en seguir editando. Depende también del periodo de vida del libro, desde que sale de imprenta hasta que se agota, cuánto tiempo estarás vendiéndolo. Muchas veces los editores quieren venderlo todo del tirón, y como calculan cuánto van a vender tal libro y en cuánto tiempo, pueden ajustar el precio.
Pasemos a comentar tu obra personal, si te parece. Respecto a Parte de todo esto, tiene la particularidad de que, a pesar de tu gusto por la autoedición, fue publicada por De Ponent, que es una editorial convencional, aunque no deja de ser pequeña.

Sí, ahí tienen que ver varias cosas. Primero una cuestión de ego, de querer ver tu nombre en un catálogo que no sea el tuyo. Después el tema económico: si yo hubiera editado Parte de todo esto me habría costado mucho y habría perdido dinero. Prefiero que pierda otro [risas]. No sé cómo habrán ido las ventas, ¿eh? Y también está el dinero que me pagaron, que no fue mucho pero me permitió editar un par de cosas en Valientes. La cuestión es que el hecho de que yo me autoedite no significa que no pueda editar con otra persona. Está bien porque a veces no sabes si lo que estás haciendo es un capricho o realmente tiene sentido, y editar con otro te da perspectiva, puedes darte cuenta de si te estabas equivocando, el editor te pone los pies en el suelo.

Hay otro proyecto que voy a dar a una editorial ahora, que igualmente podría haberlo sacado solo, pero es arriesgado, tardaría mucho, y yo sé que no soy un superventas... Un editor puede ayudarme a 


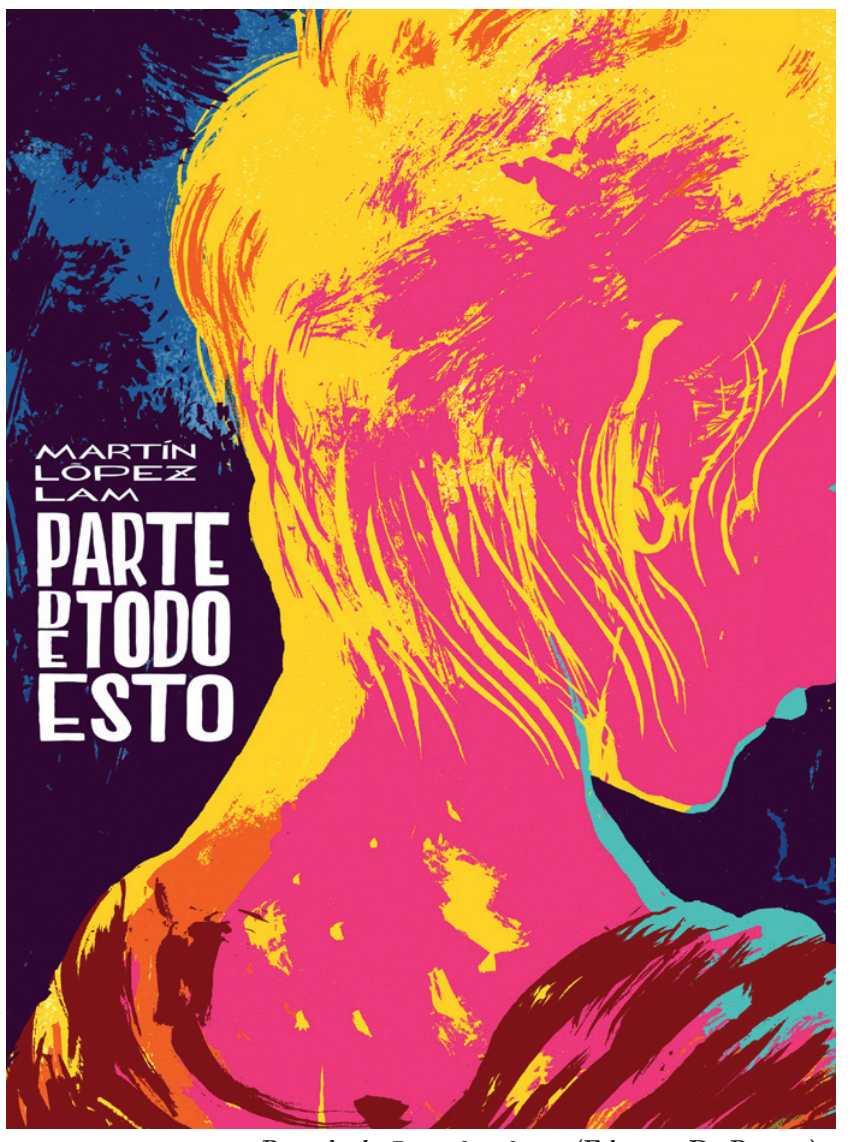

Portada de Parte de todo esto (Edicions De Ponent)

sacar esa obra, hacer que llegue a otro tipo de gente, que esta gente conozca de rebote Ediciones $\mathrm{Va}$ lientes, y que pillen los zines. Está todo conectado. La autoedición no es incompatible con publicar en otro sitio.

\section{De hecho en Parte de todo esto hay historias que habían visto la luz en Kovra.}

Sí, unas cuantas páginas, no muchas.

\section{En Parte de todo esto vemos cierta influencia li-} teraria.

Hay cierta intención literaria y también cinematográfica, aunque igual se ha notado menos. Quería que el texto tuviera ese carácter, aunque no sé si es bueno o malo que sea tan literario. Es cuestión de las influencias que uno va cogiendo de lecturas y visionados de películas. También puse mucho texto porque estaba tardando mucho en dibujarlo, y me chocaba que alguien coja un tebeo que he tardado tres años en hacer y lo lea en una hora. Por hacer que dure un poco más le fui poniendo más texto [risas]. Pero de ahí a que el texto tenga valor literario... no sé, eso creo que es otra cosa.
Es un relato clásico, asociado con una novela gráfica más tradicional... No sabemos si eso está relacionado con el hecho de que se publique en una editorial convencional.

No... Es que yo soy muy clásico, incluso cuando intento no serlo. No me atraía hacer una obra basada en el diseño de página y los juegos visuales, a lo Chris Ware, que está bastante bien, pero que a mí no me servía mucho para contar lo que quería. No quería emplear artificios ni grandes pirulas visuales para encandilar al lector. Quería que la narración clásica fuera la responsable, que el lector se interesara con ese falso movimiento que crea la secuencia. Quizás lo del texto venga un poco por ahí, al no incluir artificios visuales necesité que la palabra tuviera peso en la obra. Pero sí tenía algunas ideas muy claras antes de empezar. Si os dais cuenta, la primera historia es la más clásica de todas: completamente lineal, con una relación de causa-efecto... Cuando la hice me dije que esa historia iría primero, para que sepan que sé narrar [risas]. Y cuando acaba esa primera historia puedo empezar a jugar a otros niveles, no tener vergüenza de equivocarme. La última historia no es muy clásica, está muy fragmentada, su estructura no es lineal, y se va componiendo de momentos entrelazados entre sí como una especie de mapa mental. La idea del tiempo es distinta (pensando en cómo la representación del tiempo se ha transformado en otras artes narrativas como la literatura o el cine), se narran episodios muy distanciados entre sí, a pesar de que cuando lo lees puedes sentir una continuidad que en realidad no existe; la motiva la lectura, no los acontecimientos. En esa última historia, que se llama también "Parte de todo esto", traté de buscar una forma de trasladar el monólogo interior literario al cómic, hacer un proceso de traducción entre medios. ¿Cómo podía narrar algo que no es narrable, los sentimientos, las ideas? ¿Cómo representar mediante una narración gráfica, ideas que son abstractas, tránsitos que tienen que ver más con lo perceptual que con la palabra? ¿Cómo representas lo irrepresentable sin caer en el uso de iconos o textos explicativos? Igual pequé de querer hacer algo fuera de mis capacidades, pero fue un reto que me propuse. Quizás en el cómic, al estar tan basado en las imágenes, estamos acostumbrados a la secuencia, por eso la idea era construir el monólogo sin que hubiera una sucesión de acontecimientos. Y que se alejara del monólogo interior 


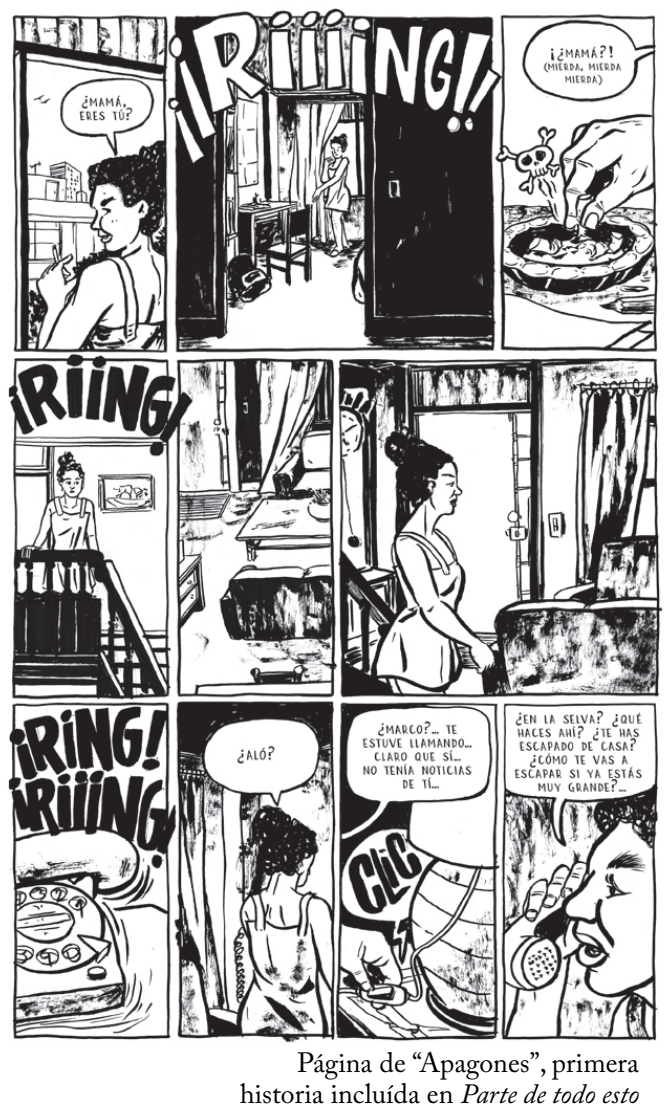

del superhéroe bajo la lluvia, en el que el cartucho de texto se emplea para explicar lo que no quieres dibujar; hacerlo sin texto, solo con imágenes.

Quizás lo que pasa es que tradicionalmente el cómic se ha orientado más a la acción que a la introspección psicológica, y a la hora de mostrar sentimientos o pensamientos los autores necesitáis generar nuevas maneras de hacer cómic.

De hecho Ware sí se ha acercado mucho al monólogo interior sin usar la palabra, sólo con imágenes. Pero yo no quería ser Chris Ware, que ya está él ahí para eso. En Asterios Polyp [de Dave Mazzucche1li] hay una secuencia que me gusta mucho, casi al final. Es una secuencia de varias páginas en las que en la parte superior aparece el pensamiento de la mujer de Asterios y en la inferior él mismo haciendo cosas. De pronto ahí sentí esa introspección en la mente del personaje, pero mucho más abstracta. Y estaba usando igualmente el lenguaje secuencial para conseguirlo. En el cine de los últimos años se ha visto un recurso parecido: de repente ves a un personaje a través de una cámara, en silencio, simplemente ves su recorrido por un espacio determinado, sin acontecimientos... Tú tienes que intuir lo que está pensando el personaje. Creo que fue Deleuze el que decía que las disciplinas artísticas eran la intersección de dos conceptos que respondían a las problemáticas de la misma naturaleza del medio, así la pintura era la relación entre el color y el espacio, el cine entre tiempo y el espacio, entonces ¿cuál es o cuáles son los problemas del cómic?

En Parte de todo esto te centras en las relaciones personales convencionales y de alguna manera las cuestionas.

Ah, ¿sî́? [risas] Tengo que decir que si ahora tuviera que hacer Parte de todo esto no lo haría, ¿eh? Fue una etapa en la que me apetecía hacerlo y que sabía que no se repetiría. Surgió de otro proyecto que no llegó a realizarse, que respondía mucho más al cómic típicamente indie. Respondía mucho a la nostalgia, y ahora que he terminado el cómic ya me puedo permitir detestar la nostalgia, la nostalgia, en cualquiera de sus expresiones o excusas, la aborrezco. Pero sí, es un cómic basado en las relaciones interpersonales, en esas situaciones en las que la fastidias, e intentas arreglarlo, pero sigues fastidiándolo... Un poco drama [risas]. En otras entrevistas he dicho que me encantan las telenovelas, y su drama tan exagerado. Me gustarías hacer telenovelas, en realidad [risas]. Parte de todo esto es muy de telenovelas, pero tenía esa pretensión pseudoartística de querer hacer algo más que eso, pero

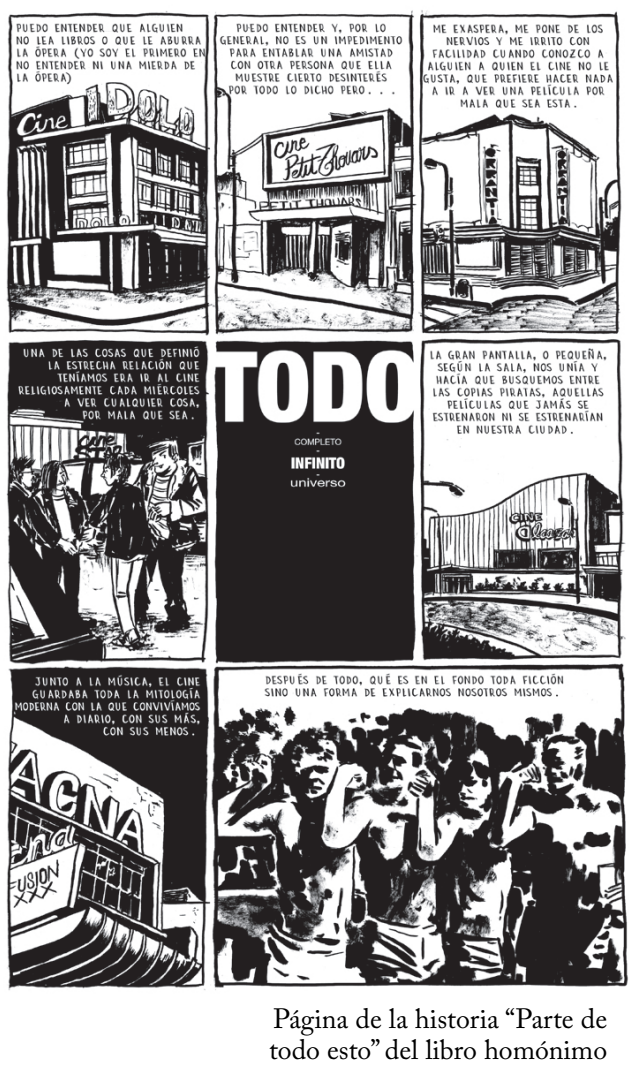


ahora ya no, ahora quiero hacer una telenovela tal cual [risas].

\section{¿Hasta qué punto es autobiográfico este cómic?}

Eso no os lo puedo decir, ahí está la trampa. Parte de experiencias propias pero también de cosas que me han contado otras personas. Y cosas inventadas, claro.

En el fondo, cuando mucha gente critica lo autobiográfico no se da cuenta de que muchas veces los autores jugáis con este equívoco.

También tienes que saber cómo contarlo. La autobiografía tiene que ser interesante o por lo menos que te encandile la forma en la que se te cuenta. A veces hay cosas que son infumables, no me interesa lo que le ha pasado al autor, si su padre ha muerto de cáncer al riñón o si es autista o si en el colegio le hacían bulling, lo que me interesa es que escriba / dibuje bien, haga un relato autobiográfico crudo o simple escapismo. La sinceridad, a veces, esta sobrevalorada, y otras veces se convierte en un exhibicionismo lastimero. Hay un escritor, Julio Ramón Ribeyro, un cuentista de los años sesenta y setenta de Perú, que es una influencia importante en mi trabajo. Escribió una especie de decálogo para escribir cuentos, y una de las normas era que todo lo que es real hay que escribirlo como si no lo fuera, y todas las cosas que no han pasado hay que escribirlas como si hubieran pasado de verdad. Es el juego de saber mentir.

Y se haga intencionadamente o no todo el que cuenta algo está haciendo un relato, aunque pretenda hacer autobiografía siempre hay invención.

Claro, hay que ser consciente de que cuando haces autobiografía estás haciendo un relato, estás ficcionando tu propia experiencia. Si eres sincero llega un momento en el que te das cuenta de que el personaje que eres tú ya no eres tú: ha obtenido vida propia. Una cosa que no soporto son los autores que intentan crear un personaje y hablar a través de él. A mí me gusta que adquiera vida propia. Es una opción personal, claro, no significa que lo otro sea malo.

Un proyecto tuyo que nos gusta mucho es Chemtrail. Surge primero como una experiencia en la web y luego pasa al papel, y es completamente rompedor con Parte de todo esto. Es un cómic casi abstracto, con un concepto muy radical detrás.

Fue un cúmulo de sucesos. Por un lado lo que he comentado antes: hacer una cosa no narrativa pero dentro de una secuencia, hacer un cómic abstracto. La idea de un cómic abstracto es un poco absurda, yo he visto pocos buenos, pero sí he visto alguno muy bueno... Eso es lo que yo quería conseguir. Hacer una secuencia a partir de una selección aleatoria de imágenes, tanto de internet como escaneadas de revistas. Y sobre todo quería convertir la narración en una experiencia, como lo que comentábamos antes del cómic para exposición, en tres dimensiones. Chemtrail va por ahí, que sea la experiencia del lector al desplazarse por la página, la imagen es más grande que la ventana del navegador y te obliga a ir de arriba a abajo y de izquierda a derecha para poder ver toda la composición. Ese recorrido debería ayudar al lector a construir la historia, si es que hay una, o simplemente a seguir un juego, la experiencia narrativa...

\section{O estética...}

Bueno, estética siempre lo va a ser. La intención es que fuera narrativa. Estamos hablando de narración en el sentido de secuencia de imágenes, que puede o no estar contándote algo. Tú puedes montar una historia o no, pero lo que tiene que estimularte es recorrer ese espacio, haciendo scroll en el navegador, pinchando enlaces... O abriendo una caja en el caso de Fabricar historias. Se trata de que no sea la típica experiencia de pasar páginas o de hacer clic tras clic en un webcómic. En realidad fue un juego. En el about de la página explico que esto se inspira en el cine expandido y en Dogstarman de Stan Brakhage, una serie de peliculas realizadas a partir de variaciones en el montaje de diferentes grabaciones que había hecho en la montaña. Mi intensión primera era ir haciendo diferentes montajes de Chemtrail pero la pereza ganó y ahí sigue.

\section{¿El proyecto de Chemtrail está cerrado ya?}

Hay dos números, y la idea es seguir remontando lo que hay, y hacer más números. Y también llevarlo a una sala, hacerlo en tres dimensiones, con luces estroboscópicas y sonidos creados a partir de 

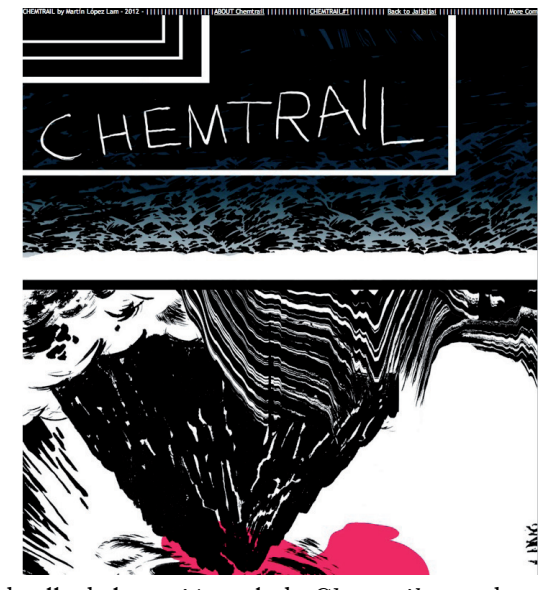

Un detalle de la versión web de Chemtrail, tomado a las 17:14 del 19 de diciembre de 2014

las famosas trompetas del apocalipsis, el hum. Será algo muy discotequero y hortera. Igual así ya no tendría que ver ni con el cómic ni con la web.

O sea que no es solo que haya trasvase de medios entre la web y el papel sino que se expande. ¿Cómo has enfrentado esta diferencia de medios?

El tema del webcómic para tablets o para i-pads es más sencillo, y creo que acabará siendo otra cosa y no se le llamará cómic, surgirá otra denominación. Creo que es un arte nuevo que aún no sabría definir, que responde a la tecnología que lo hace posible.
Otro fanzine tuyo es Dote de poto a tres, en el que de alguna manera recuperas el universo de De parte de todo esto pero lo deformas o lo deconstruyes, no sabemos cuál sería la palabra adecuada.

Es un dos por uno. Pasé tanto tiempo dibujando Parte de todo esto que al final no todas las viñetas me gustaban. Pero cogí las que sí e hice otra historia. Tiene que ver también con las remezclas de Tonto Comics y con Chemtrail, la idea del montaje, de cómo puede cambiar una historia simplemente cambiando el orden de las viñetas. Fue un ejercicio, y en realidad tiene cierta relación, nacieron juntas y sus títulos son anagramas, pero son historias completamente diferentes. Creo que hay gente a la que le gusta mucho más Dote de poto a tres que Parte de todo esto, porque es algo mucho más inmediato. Lo escribí en dos noches y luego simplemente fue montarlo. Tiene mucho más que ver con lo lírico que con contar algo, además. A mí personalmente también me gusta más que Parte de todo esto.

A nosotros nos da la sensación de que lo que hiciste fue coger una obra en la que tú ya no estabas como autor, porque tus intereses parecían ser

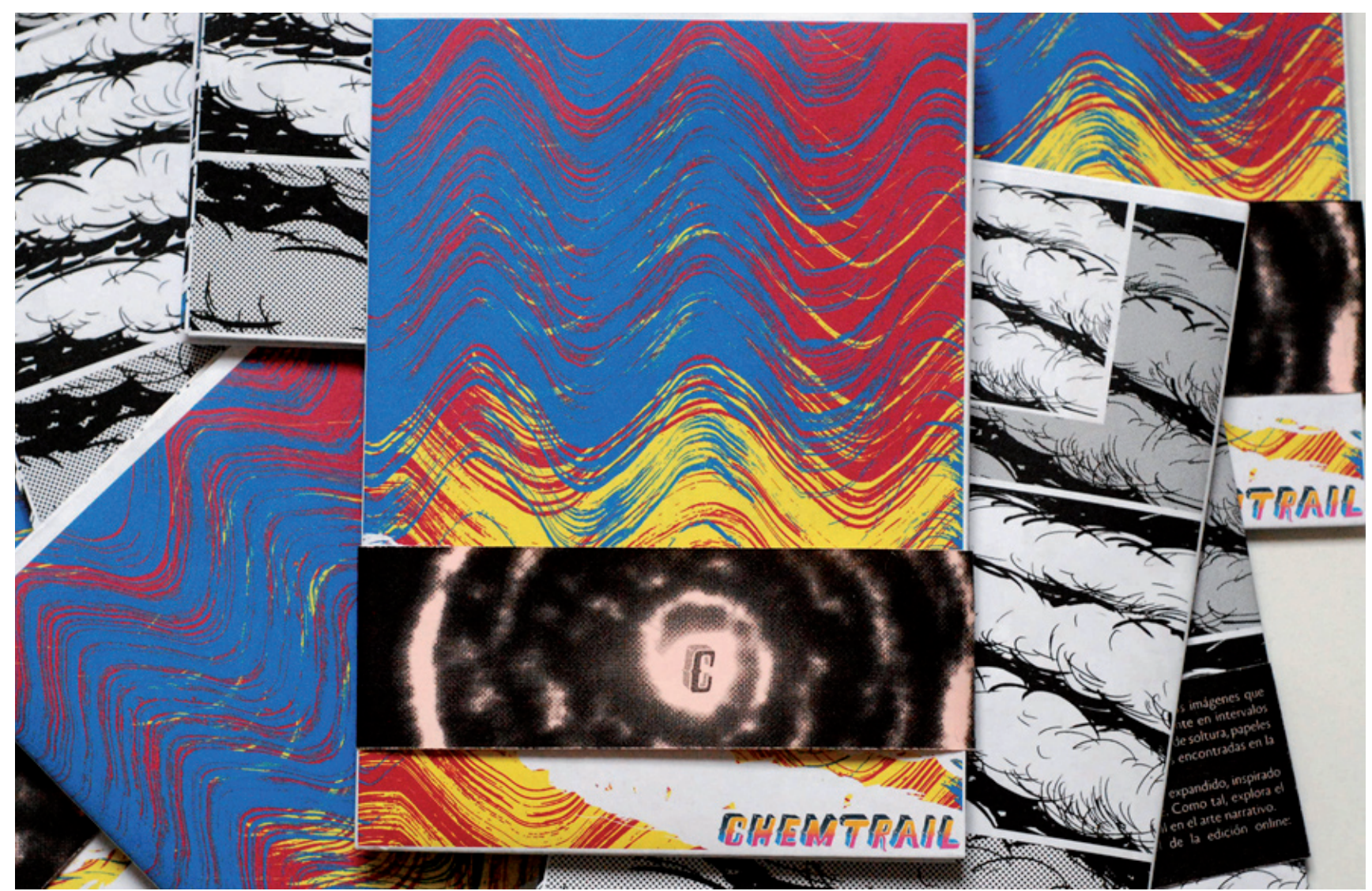

Edición en papel de Chemtrail 


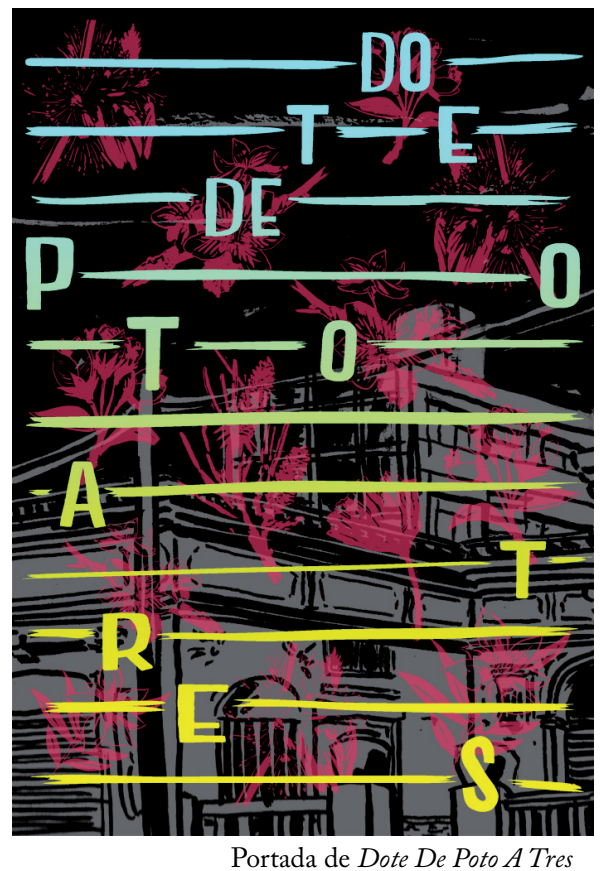

otros, y llevártela a tus coordenadas actuales, con la experimentación con el montaje y demás.

Sí, las últimas cosas que he hecho van por ahí. Ahora mismo mi forma de trabajar es hacer varios dibujos pequeños, y cuando ya tengo una idea en la cabeza los voy ordenando. Tiene que ver un poco con el free jazz. Escupirlo todo, hacer una maraña e ir moldeándola, antes que pensar en el conjunto, hacer una estructura y una planificación e ir poco a poco. Con eso sí recupero cierta inmediatez frente al artificio del cómic que el proceso muchas veces va borrando, todo está tan elaborado que la inmediatez que te da una imagen capturada, digamos, de la calle, como en el cine, en el cómic es imposible.

Antes has mencionado Capitán Tsubasa; con él has hecho un experimento en un pequeño fanzine...

Sí, Atom. Fue una broma [risas]. Después quise hacer una cosa con Conan que tengo por ahí guardada. Son cosas que si no se hacen con la frescura del momento, si las piensas, se pasan. Atom fue una rallada de un momento, nada más [risas].

¿Qué posibilidades le ves al color en tu obra? Mayoritariamente es en blanco y negro.

Básicamente uso el blanco y negro porque es más rápido y lo puedo reproducir económicamente en fanzines. Para web sí he hecho algunas cosas en co- lores, pero cuando he intentado hacer un cómic largo en color... No me gusta cómo coloreo en conjunto. Funciona bien en una imagen pero en una secuencia de una página no. El color es un misterio tan grande para mí que se me escapa de las manos. Espero aprender a colorear páginas algún día [risas]. En general cuando coloreo satura mucho, hay muchos contrastes... le quita más de lo que aporta al resultado.

Tras todo lo que hemos comentado nos damos cuenta, realmente, de que los autores de tu generación, que os movéis en este circuito, formáis una verdadera comunidad. Incluso internacional.

Sí, creo que en parte es así, aunque en todas partes se cuecen habas. Cada uno luego tiene su propio valor como nombre propio, pero creo que la $\mathrm{co}^{-}$ munión entre autores que se está generando y el trabajo colaborativo es lo más valioso. Buscar el bien común. También hay quienes creen en la individualidad y piensan que las antologías son una pérdida de tiempo, y quizá tengan razón, ya no se editan antologías, el nombre de un autor tiene valor por sí mismo pero no como un conjunto, y esto es algo que a mí no me llega a agradar del todo... Creo que esto de lo comunitario también tiene que ver con todo lo que está pasando a nivel social. Quiero pensar en colectivos de dibujantes haciendo cosas para pequeños grupos autónomos antes que en estrellas y best sellers que alimentan una industria fantasma. No sé si esto será el futuro o no pero por el momento es divertido pensarlo haciéndolo y hacerlo pensándolo. Por eso lo hacemos, si no lo fuera no tendría sentido.

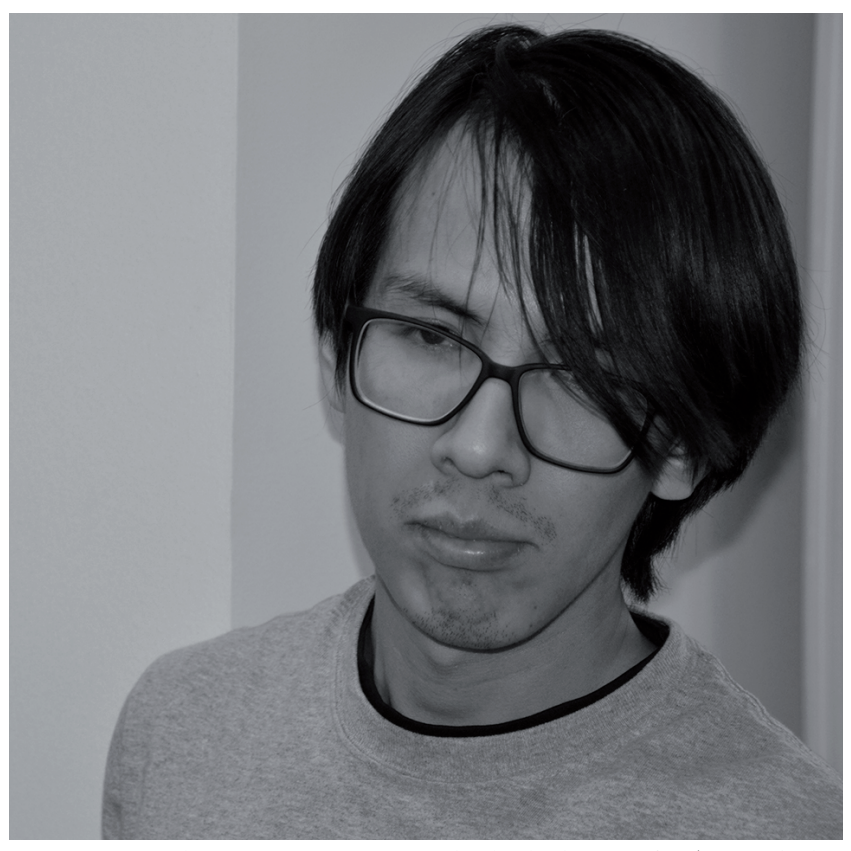

El autor en un momento de charla durante GRAF Madrid. Fotografía de Alejandro López Menacho 